\title{
Audit Report Lag Memediasi Pengaruh Financial Distress dan GCG pada Ketepatan Waktu Publikasi Laporan Keuangan
}

\author{
Ni Luh Putu Ita Nopayanti ${ }^{1}$ \\ Dodik Ariyanto ${ }^{2}$ \\ ${ }^{1}$ Fakultas Ekonomi dan Bisnis Universitas Udayana (Unud), Bali, Indonesia \\ email: itanopayanti02@gmail.com/Telp:+6285737188373 \\ ${ }^{2}$ Fakultas Ekonomi dan Bisnis Universitas Udayana (Unud), Bali, Indonesia
}

\begin{abstract}
ABSTRAK
Perusahaan go public wajib untuk menyampaikan laporan keuangan yang telah daudit secara tepat waktu. Faktor intern perusahaan dan auditor independen dapat mempengaruhi ketepatan waktu publikasi laporan keuangan. Tujuan penelitian ini adalah untuk memperoleh bukti empiris pengaruh financial distress dan GCG pada ketepatan waktu publikasi laporan keuangan dengan audit report lag sebagai variabel intervening. Jumlah sampel yang diambil adalah sebanyak 45 sampel dengan menggunakan metode purposive sampling. Pengumpulan data dilakukan dengan menggunakan metode observasi non partisipan. Teknik analisis data yang digunakan adalah teknik analisis jalur (path analysis). Hasil penelitian menunjukan bahwa financial distress berpengaruh positif pada audit report lag. GCG berpengaruh negatif pada audit report lag. Financial distress dan GCG tidak berpengaruh pada ketepatan waktu publikasi laporan keuangan. Financial distress dan GCG berpengaruh pada ketepatan waktu publikasi laporan keuangan melalui audit report lag.

Kata kunci:Ketepatan waktu publikasi laporan keuangan, financial distress, GCG, audit report lag
\end{abstract}

\begin{abstract}
Go pubic companies are required to submit audited financial statements in a timely manner. Internal factors of the company and the independent auditor may affect the timeliness of financial statement publication. The purpose of this study is to obtain empirical evidence of the influence of financial distress and GCG on the timeliness of financial statement publication, with audit report lag as intervening variable. Samples are taken about 45 samples with purposive sampling method. Data was collected by non participant observation method. Data analysis technique using path analysis. The results showed that financial distress positively affect the audit report lag. GCG has a negative effect on audit report lag. Financial distress and GCG have no effect on the timeliness of financial statement publication. Financial distress and GCG affect the timeliness of financial statement publication through audit report lag.

Keywords: Timeliness of financial statement publication, financial distress, GCG, audit report lag
\end{abstract}

\section{PENDAHULUAN}

Laporan keuangan adalah informasi keuangan suatu perusahaan pada suatu periode akuntansi yang dapat digunakan untuk menggambarkan kinerja perusahaan. Ada 3 kriteria utama yang dapat digunakan untuk menilai kualitas 
laporan keuangan perusahaan, diantaranya ialah ketepatwaktuan, keandalan, dan komparabilitas (Owusu-Ansah \& Yeoh, 2005). Informasi yang terkandung dalam laporan keuangan harus memiliki relevansi yang baik, sehingga informasi tersebut harus disajikan tepat waktu. Jika terdapat penundaan dalam pelaporan, maka informasi yang dihasilkan akan kehilangan relevansinya (Hilmi dan Ali, 2008).

Abdulla (1996) dalam Ahmad dan Kamarudin (2003), serta Aziz et al. (2014) mengemukakan bahwa semakin pendek rentang waktu antara akhir tahun buku dan tanggal publikasi laporan keuangan, maka semakin besar manfaat yang dapat diperoleh dari laporan keuangan. Ketepatwaktuan menurut SFAC No. 2 adalah tersedianya informasi dalam pengambilan keputusan sebelum informasi tersebut kehilangan kapasitas pengaruhnya dalam mempengaruhi keputusan. Owusu dan Ansah (2000) berpendapat secara konseptual ketepatwaktuan adalah kualitas ketersediaan informasi pada saat yang diperlukan atau kualitas informasi yang baik dilihat dari segi waktu.

Tuntutan akan kepatuhan terhadap ketepatwaktuan dalam menyampaikan laporan keuangan di Indonesia telah diatur dalam peraturan Bapepam yang saat ini telah menyatu dalam Otoritas Jasa Keuangan (OJK). Peraturan tersebut yakni Keputusan Ketua Badan Pengawas Pasar Modal dan Lembaga Keuangan Nomor: KEP-431/BL/2012 tentang penyampaian laporan tahunan emiten atau perusahaan publik yang ditetapkan sejak tanggal 1 Agustus 2002. Namun, KEP-431/BL/2012 tanggal 1 Agustus 2012 dicabut dan dinyatakan tidak berlaku pada tanggal 1 Januari 2017. Keputusan ini digantikan oleh Peraturan OJK No. 29/POJK.04/2016 mengenai laporan tahunan emiten atau perusahaan publik. Peraturan tersebut 
menyatakan bahwa perusahaan publik wajib menyampaikan laporan tahunan perusahaan kepada OJK paling lambat pada akhir bulan keempat atau 120 hari setelah tahun buku berakhir.

Sampai saat ini ketepatan waktu publikasi laporan keuangan belum diimplementasikan secara maksimal. Perusahaan yang terdaftar di Bursa Efek Indonesia (BEI) masih banyak yang mengalami keterlambatan publikasi laporan keuangan. Hal ini dibuktikan dengan adanya peningkatan keterlambatan publikasi laporan keuangan yang dicatat oleh BEI, dengan data sebagai berikut.

Tabel 1.

Jumlah Perusahaan Publik yang Terlambat dalam Publikasi Laporan Keuangan Tahun 2012-2016

\begin{tabular}{cc}
\hline Tahun & Jumlah Perusahaan \\
\hline 2012 & 54 emiten untuk LK tahun 2011 \\
2013 & 52 emiten untuk LK tahun 2012 \\
2014 & 17 emiten untuk LK tahun 2013 \\
2015 & 52 emiten untuk LK tahun 2014 \\
2016 & 63 emiten untuk LK tahun 2015 \\
\hline
\end{tabular}

Sumber: Data diolah, 2017

Berdasarkan data di atas, sejak tahun 2014 hingga 2016 terjadi penambahan keterlambatan pelaporan keuangan untuk LK tahun 2013 hingga 2015. Berdasarkan data tersebut diketahui bahwa ketepatan waktu masih menjadi kendala bagi perusahaan, dan regulasi yang ada tidak dapat menjadi satu-satunya faktor yang mempengaruhi perusahaan untuk melaporkan laporan keuangan tahunan sesuai dengan waktu yang telah ditetapkan. Berbagai penelitian telah dilakukan dalam menganalisis faktor-faktor yang memengaruhi ketepatan waktu publikasi laporan keuangan di Indonesia, salah satunya adalah financial distress. 
Menurut Julien (2013) perusahaan banyak yang terlambat dalam pelaporan keuangannya ke publik karena adanya pengunduran penerbitan laporan keuangan. Pengunduran penerbitan tersebut dapat terjadi karena adanya bad news dalam laporan keuangan. Bad news tersebut salah satunya adalah kesulitan keuangan. Perusahaan akan berusaha untuk membenahi laporan keuangan yang mengandung bad news untuk menghindari kualitas laporan yang buruk. Proses dalam membenahi laporan keuangan memerlukan waktu yang tidak sebentar, sehingga dapat menyebabkan keterlambatan dalam menyampaikan laporan keuangan.

Kadir (2008) dan Robert (2015) menyatakan bahwa financial distress tidak berpengaruh pada ketepatwaktuan penerbitan laporan keuangan. Julien (2013) menemukan bukti bahwa kesulitan keuangan tidak mampu mempengaruhi keterlambatan pelaporan keuangan ke publik. Krisnanda dan Ratnadi (2017) serta Budiasih dan Saputri (2014) juga mengemukakan bahwa financial distress tidak memiliki pengaruh yang signifikan pada kecepatan publikasi laporan keuangan. Penelitian tersebut dibantah oleh Mardyana (2014) dan Narayana (2016) yang mengemukakan bahwa financial distress mampu mempengaruhi ketepatwaktuan penerbitan laporan keuangan ke publik. Pernyataan tersebut didukung oleh Persephony (2013), bahwa probabilitas kebangkrutan yang ditunjukan dengan nilai z-score berpengaruh positif pada waktu publikasi laporan keuangan.

Faktor lainnya yang diindikasi dapat mempengaruhi ketepatan waktu penerbitan laporan keuangan adalah Good Corporate Governance (GCG). Perusahaan harus menyajikan informasi yang relevan dengan cara mudah diakses dan dimengerti oleh pemangku kepentingan. Apabila perusahaan menerapkan 
prinsip-prinsip GCG dalam suatu perusahaan dan menjalankannya sesuai dengan peraturan, maka penyampaian laporan keuangan ke publik akan semakin cepat karena kriteria laporan keuangan yang baik sudah terpenuhi. Menurut Narayana (2016) perusahaan yang memiliki kinerja baik cenderung akan mempublikasikan laporan keuangan perusahaan dengan tepat waktu.

Pengaruh GCG pada ketepatan waktu publikasi laporan keuangan dibuktikan dengan adanya penelitian oleh Clatworthy (2010) menyatakan bahwa perusahaan di Inggris berdasarkan prinsip yang ada dalam GCG berpengaruh pada kecepatan publikasi laporan keuangan. Dewi (2016) berpendapat bahwa GCG memiliki pengaruh negatif pada kecepatan penyampaian laporan keuangan. Namun, pernyataan tersebut dibantah oleh Fitriani (2011) yang mengungkapkan bahwa GCG tidak mampu mempengaruhi ketepatan waktu pelaporan keuangan ke publik. Selanjutnya, McGee dan Yuan (2008) mengungkapkan bahwa laporan keuangan perusahaan China kurang tepat waktu jika dibandingkan dengan laporan keuangan perusahaan non China, walaupun kedua perusahaan tersebut telah menerapkan GCG di perusahannya.

Menurut Kartika (2009), ketepatan waktu publikasi laporan keuangan perusahaan kepada public juga tergantung dari waktu auditor dalam menyelesaikan pekerjaan auditnya. Rentang waktu penyelesaian audit atas laporan keuangan disebut dengan audit report lag atau dalam penelitian lain juga disebut sebagai audit delay. Menurut F. Ben et al. (2001) ada dugaan dalam literatur empiris bahwa audit report lag merupakan penyebab utama keterlambatan pelaporan keuangan. Menurut Persephony (2013) rentang waktu penyelesaian 
audit dapat mempengaruhi waktu penerbitan laporan keuangan. Semakin cepat proses dalam mengaudit laporan keuangan, semakin cepat pula waktu pelaporan keuangan ke publik, dan begitu juga sebaliknya.

Financial distress dan GCG juga merupakan faktor-faktor yang mempengaruhi audit report lag atau audit delay. Hal ini dibuktikan dengan adanya penelitian terdahulu yang meneliti faktor-faktor yang dapat mempengaruhi audit report lag. Sugita dan Dwirandra (2017) menyatakan bahwa financial distress berpengaruh negatif pada audit report lag. Hal tersebut sejalan dengan penelitian Julien (2013) yang menyatakan bahwa perusahaan yang mengalami financial distress tidak akan mempengaruhi reaksi pasar sehingga hal ini tidak akan menghambat perusahaan untuk mempublikasikan laporan keuangannya secara tepat waktu. Namun, penelitian tersebut dibantah oleh penelitian Praptika dan Rasmini (2016) yang mengemukakan bahwa financial distress memiliki pengaruh positif pada audit delay. Setyahadi (2012) dan Santosa (2016) menyatakan bahwa probabilitas kebangkrutan berpengaruh positif terhadap audit delay.

Pengaruh GCG pada audit report lag dibuktikan dengan penelitian terdahulu sebagai berikut. Mohamad-Nor, et al. (2010) mengemukakan bahwa ukuran komite audit dan rapat komite audit memiliki pengaruh negatif terhadap audit report lag, sedangkan independensi komite audit dan keahlian keuangan komite audit tidak berpengaruh pada audit report lag. Independensi dewan memiliki hubungan positif yang lemah pada audit report lag, ukuran dewan yang besar dapat memperburuk audit report lag, dan dualitas CEO dapat mengurangi 
audit report lag walaupun tidak signifikan. Wardhani dan Raharja (2013) meneliti pada perusahaan yang terdaftar di BEI menemukan bahwa jumlah angota komite audit, rapat komite audit, dan komisaris independen tidak berpengaruh pada audit report lag, independensi komite audit dan kompetensi anggota komite audit memiliki pengaruh negatif pada audit report lag, dan ukuran dewan memiliki pengaruh positif pada audit report lag.

Audit report lag dapat dipengaruhi oleh financial distress dan GCG, serta mempengaruhi ketepatan waktu penerbitan laporan keuangan sehingga audit report lag dipilih menjadi variabel intervening dalam penelitian ini. Selain alasan tersebut, untuk menerbitkan laporan keuangan perusahaan diwajibkan untuk mengaudit laporan keuangannya terlebih dahulu. Jangka waktu penyelesaian audit memiliki konsekuensi besar dalam laporan keuangan karena laporan keuangan yang disampaikan harus disertai pernyataan dari auditor.

Teori keagenan dideskripsikan sebagai hubungan antara pemegang saham sebagai principal dan manajemen sebagai agent (Jensen dan Meckling, 1976). Hal yang difokuskan pada teori ini ialah mengenai pencapaian kontrak paling efisien yang menjadi dasar hubungan antara prinsipal dan agen. Namun, pada kenyataannya kontrak yang terjadi sering kali tidak berjalan secara efisien karena salah satu pihak yaitu prinsipal atau agen mempunyai informasi yang lebih banyak yang dapat menyebabkan hubungan antara prinsipal dan agen dilandasi oleh asimetri informasi. Ketepatan waktu publikasi laporan keuangan diharapkan dapat mengurangi asimetri informasi antara perusahaan dengan pemakai laporan keuangan. Penyampaian laporan keuangan yang tepat waktu akan mengurangi 
kecurangan pihak agen sebagai pihak yang memiliki informasi yang lebih banyak dibandingkan dengan pihak prinsipal untuk memanipulasi data (Narayana, 2016).

Whittred dan Zimmer (1984) dalam Setyahadi (2012) mengemukakan bahwa perusahaan yang sedang mengalami kesulitan keuangan berhubungan dengan audit report lag. Perusahaan yang sedang mengalami financial distress akan cenderung mengalami audit report lag yang panjang. Hal tersebut sejalan dengan Dwipayani, dkk (2016) serta Walker dan David (2008) menyatakan bahwa probabilitas kebangkrutan berpengaruh pada audit delay. Setyahadi (2012) dan Santosa (2016) menyatakan bahwa probabilitas kebangkrutan berpengaruh positif terhadap audit delay. Penelitian Praptika dan Rasmini (2016) menemukan hasil bahwa financial distress berpengaruh positif pada audit delay. Berdasarkan hal tersebut, maka dapat diajukan hipotesis pertama sebagai berikut.

$\mathrm{H}_{1}$ : Financial distress berpengaruh positif pada audit report lag.

Adanya praktik corporate governance dalam suatu perusahaan diharapkan tidak terjadi kecurangan dalam penyusunan laporan keuangan oleh manajemen yang dapat menyebabkan panjangnya waktu penyelesaian audit. Adanya GCG diharapkan perusahaan dapat melakukan pengawasan terhadap auditor sehingga dapat mengurangi audit report lag (Faishal \& Hadiprajitno, 2015). DS dan Nelyumna (2016) dalam penelitiannya menyatakan bahwa GCG dengan proksi komite audit dan dewan komisaris memiliki pengaruh signifikan terhadap audit delay. Faishal dan Hadiprajitno (2015) menyatakan bahwa mekanisme GCG memiliki pengaruh signifikan terhadap audit report lag. Bemby S, et al. (2013) dalam penelitiannya menyatakan bahwa mekanisme GCG secara simultan 
berpengaruh pada audit delay. Berdasarkan hal tersebut, maka dapat diajukan hipotesis kedua sebagai berikut.

$\mathrm{H}_{2}$ : Good corporate governance berpengaruh negatif pada audit report lag.

Financial distress adalah tahap penurunan kondisi keuangan yang dialami oleh suatu perusahaan, yang terjadi sebelum kebangkrutan ataupun likuidasi (Platt dan Platt, 2002). Probabilitas kebangkrutan yang tinggi merupakan suatu berita buruk sehingga manajemen perusahaan akan berusaha untuk mengundur penerbitan berita buruk tersebut ke publik (Persephony, 2013). Mardyana (2014) dan Narayana (2016) menemukan bahwa financial distress dapat mempengaruhi penurunan ketepatwaktuan penerbitan laporan keuangan. Persephony (2013) menyatakan bahwa probabilitas kebangkrutan berpengaruh positif pada waktu publikasi laporan keuangan. Berdasarkan hal tersebut, maka dapat diajukan hipotesis ketiga sebagai berikut.

$\mathrm{H}_{3}$ : Financial distress berpengaruh positif pada ketepatan waktu publikasi laporan keuangan.

Penerapan kelima prinsip-prinsip GCG secara konsisten sangatlah penting, karena dapat meningkatkan kualitas laporan keuangan perusahaan. Apabila sebuah perusahaan melaksanakan prinsip-prinsip tersebut dengan baik, maka penerbitan laporan keuangan perusahaan akan semakin cepat karena kriteria laporan keuangan yang baik sudah terlaksana. Penelitian sebelumnya yang dilakukan oleh Widyastuti (2010) dan Mumtaz (2011) menyatakan bahwa kualitas GCG berpengaruh terhadap ketepatan waktu penyampaian laporan keuangan. Clatworthy (2010) mengemukakan bahwa perusahaan di Inggris berdasarkan prinsip yang ada dalam GCG mampu mempengaruhi kecepatan penyampaian 
laporan keuangan. Dewi (2016) berpendapat bahwa GCG memiliki pengaruh negatif pada kecepatan penerbitan laporan keuangan. Berdasarkan hal tersebut, maka dapat diajukan hipotesis keempat sebagai berikut.

$\mathrm{H}_{4}$ : Good Corporate Governance berpengaruh negatif pada ketepatan waktu publikasi laporan keuangan.

Penyelesaian laporan audit perusahaan merupakan faktor penting dalam menentukan ketepatan waktu publikasi laporan tahunan perusahaan (Alkhatib dan Marji, 2012). Keterlambatan penerbitan laporan keuangan dapat menandakan adanya masalah dalam laporan keuangan perusahaan publik sehingga memerlukan waktu yang lebih lama dalam menyelesaikan audit (Utami, 2006). Oleh karena itu, semakin cepat pengauditan laporan keuangan perusahaan, maka semakin cepat pula waktu penerbitan laporan keuangan dan begitu juga sebaliknya (Persephony, 2013). Ahmed dan Hossain (2010) dalam penelitiannya menyatakan bahwa audit report lag merupakan alasan utama penundaan laporan keuangan. Persephony (2013) dalam penelitiannya menyatakan bahwa audit report lag berpengaruh positif terhadap waktu publikasi laporan keuangan. Hal ini juga sejalan dengan penelitian Dinita (2011) dan Putri dkk. (2017) yang menyatakan bahwa audit report lag berpengaruh terhadap ketepatan waktu penyampaian laporan keuangan. Berdasarkan hal tersebut, maka dapat diajukan hipotesis kelima sebagai berikut.

$\mathrm{H}_{5}$ : Audit report lag berpengaruh positif pada ketepatan waktu publikasi laporan keuangan.

Suatu perusahaan yang terindikasi mengalami financial distress cenderung akan menunda publikasi laporan keuangannya karena hal tersebut merupakan suatu berita buruk bagi perusahaan. Perusahaan yang sedang menghadapi 
financial distress akan cenderung mengalami audit report lag yang panjang. Semakin tinggi probabilitas kebangkrutan (semakin rendah Z-Score) berarti semakin panjang penyelesaian auditnya sehingga waktu penerbitan laporan keuangan ke publik akan tertunda (Persephony, 2013). Berdasarkan uraian di atas, maka dapat diajukan hipotesis keenam sebagai berikut.

$\mathrm{H}_{6}$ : Financial distress berpengaruh pada ketepatan waktu publikasi laporan keuangan melalui audit report lag.

Ketika pelaksanaan tata kelola perusahaan baik, maka perusahaan akan cenderung mempercepat publikasi laporan keuangannya karena terdapat pengendalian internal yang baik sebagai salah satu syarat pelaksanaaan GCG. Adanya penerapan GCG dalam perusahaan juga diharapkan dapat melakukan pengamatan terhadap auditor sehingga dapat mengurangi lamanya penyelesaian audit. Jadi, semakin baik tata kelola suatu perusahaan maka akan semakin pendek audit report lagnya sehingga publikasi laporan keuangan semakin tepat waktu. Berdasarkan hal tersebut, maka dapat diajukan hipotesis ketujuh sebagai berikut.

$\mathrm{H}_{7}$ : Good corporate governance berpengaruh pada ketepatan waktu publikasi laporan keuangan melalui audit report lag.

\section{METODE PENELITIAN}

Penelitian ini menggunakan pendekatan kuantitatif yang berbentuk asosiatif. Variabel terikat dalam penelitian ini ialah Ketepatan Waktu Publikasi Laporan Keuangan (Y). Variabel bebas dalam penelitian ini ialah Financial Distress $\left(\mathrm{X}_{1}\right)$ dan GCG $\left(\mathrm{X}_{2}\right)$. Sedangkan variabel intervening atau variabel mediasi dalam penelitian ini ialah Audit Report Lag (M). Populasi yang digunakan dalam penelitian ini adalah seluruh perusahaan yang tercatat di BEI tahun 2011-2015. 
Ni Luh Putu Ita Nopayanti dan Dodik Ariyanto. Audit ...

Penelitian ini menggunakan metode probability purposive sampling untuk pengambilan sampelnya. Metode pengumpulan data yang digunakan adalah metode observasi non partisipan.

Data kuantitatif dalam penelitian ini adalah laporan keuangan, data tanggal publikasi laporan keuangan, dan tanggal laporan auditor pada perusahaan di BEI yang terdaftar dalam penilaian CGPI tahun 2011-2015. Sedangkan data kualitatif dalam penelitian ini yaitu nama-nama perusahaan yang terdaftar di BEI dan terdaftar dalam penilaian CGPI tahun 2011-2015. Sumber data dalam penelitian ini didapat dari laporan keuangan tahunan yang telah diaudit yang terdaftar di BEI tahun 2011-2015. Penelitian ini menggunakan teknik analisis jalur (path analysis) untuk pengolahan data. Teknik analisis jalur merupakan perluasan dari analisis regresi linier berganda, yang digunakan untuk memeriksa pengaruh variabel intervening yang digunakan dalam penelitian ini. Taraf nyata yang dipakai untuk menguji analisis jalur adalah 5\%.

\section{HASIL DAN PEMBAHASAN}

Sampel dalam penelitian ini didapat dengan menggunakan teknik purposive sampling sesuai dengan kriteria yang telah ditetapkan sebelumnya. Hasil pemilihan sampel dapat dilihat pada Tabel 2 sebagai berikut.

Tabel 2.

Hasil Seleksi Pemilihan Sampel

\begin{tabular}{|c|c|c|}
\hline No & Kriteria & Jumlah \\
\hline 1 & Perusahaan yang terdaftar dalam BEI & 555 \\
\hline 2 & $\begin{array}{l}\text { Perusahaan di BEI yang tidak terdaftar dalam pemeringkatan CGPI secara } \\
\text { berturut-turut tahun 2011-2015 }\end{array}$ & $(546)$ \\
\hline 3 & $\begin{array}{l}\text { Perusahaan yang tidak menyajikan angka-angka dalam laporan keuangan } \\
\text { dengan mata uang rupiah }\end{array}$ & $(0)$ \\
\hline 4 & Perusahaan yang tidak memiliki data lengkap terkait variabel yang diperlukan & $(0)$ \\
\hline \multicolumn{2}{|r|}{ Jumlah sampel penelitian } & 9 \\
\hline \multicolumn{2}{|c|}{ Total sampel dalam lima tahun penelitian } & 45 \\
\hline
\end{tabular}

Sumber: Data diolah, 2017 
Hasil dari pengujian statistik deskriptif dalam penelitian ini dapat dilihat pada tabel 3 berikut ini.

Tabel 3.

Hasil Uji Statistik Deskriptif

\begin{tabular}{lrrrrr}
\hline & N & Minimum & Maximum & \multicolumn{1}{c}{ Mean } & \multicolumn{1}{c}{$\begin{array}{c}\text { Std. } \\
\text { Deviation }\end{array}$} \\
\hline FD & 45 & 1,00 & 3,00 & 2,2667 & 0,68755 \\
GCG & 45 & 2,00 & 3,00 & 2,7333 & 0,44721 \\
ARL & 45 & 16,00 & 82,00 & 47,8889 & 17,77795 \\
KWPLK & 45 & 23,00 & 120,00 & 61,3778 & 22,08382 \\
Valid N & 45 & & & & \\
(listwise) & & & & & \\
\hline \multicolumn{2}{l}{ Sumber: Data diolah, 2017} & & & &
\end{tabular}

Berdasarkan tabel 3 di atas dapat diketahui bahwa jumlah observasi (N) sebanyak 45. Variabel ketepatan waktu publikasi laporan keuangan mempunyai nilai maksimum sebesar 120 hari yang terdapat pada PT Bank Tabungan Negara (Persero) Tbk pada tahun 2015, sedangkan nilai minimum sebesar 23 hari terdapat pada PT Bank Rakyat Indonesia (Persero) Tbk pada tahun 2013. Ketepatan waktu publikasi laporan keuangan memiliki nilai mean sebesar 61,3778 hari yang memiliki arti rata-rata ketepatan waktu publikasi laporan keuangan pada sampel yang digunakan dalam penelitian ini berjumlah 61,3778 hari. Nilai deviasi standar ketepatan waktu publikasi laporan keuangan adalah sebesar 22,08382 yang berarti bahwa terjadi penyimpangan nilai ketepatan waktu publikasi laporan keuangan pada nilai rata-ratanya sebesar 22,08382.

Variabel audit report lag mempunyai nilai maksimum sebesar 82 hari yang terdapat pada PT Jasa Marga (Persero) Tbk pada tahun 2011, sedangkan nilai minimum sebesar 16 hari terdapat pada PT Bank Rakyat Indonesia (Persero) Tbk pada tahun 2013 dan tahun 2014. Audit report lag memiliki rata-rata (mean) sebesar 47,8889 hari yang berarti bahwa rata-rata audit report lag pada sampel 
Ni Luh Putu Ita Nopayanti dan Dodik Ariyanto. Audit ...

yang digunakan dalam penelitian ini berjumlah 47,8889 hari. Nilai deviasi standar audit report lag adalah sebesar 17,77795 yang berarti bahwa terjadi penyimpangan nilai audit report lag pada nilai rata-ratanya sebesar 17,77795.

Variabel financial distress mempunyai nilai maksimum sebesar 3, sedangkan nilai minimum sebesar 1. Financial distress memiliki rata-rata (mean) sebesar 2,2667 yang berarti bahwa rata-rata financial distress pada sampel yang digunakan dalam penelitian ini berjumlah 2,2667. Nilai seviasi standar financial distress adalah sebesar 0,68755 yang berarti bahwa terjadi penyimpangan nilai financial distress pada nilai rata-ratanya sebesar 0,68755. Variabel GCG mempunyai nilai maksimum sebesar 3, sedangkan nilai minimum sebesar 2. GCG memiliki rata-rata (mean) sebesar 2,7333 yang berarti bahwa rata-rata GCG pada sampel yang digunakan dalam penelitian ini berjumlah 2,7333. Nilai deviasi standar GCG adalah sebesar 0,44721 yang berarti bahwa terjadi penyimpangan nilai GCG pada nilai rata-ratanya sebesar 0,44721 .

Tabel 4.

Hasil Uji Asumsi Klasik Persamaan Regresi 1

\begin{tabular}{|c|c|c|c|c|c|c|}
\hline \multirow{2}{*}{$\begin{array}{l}\text { Parameter } \\
\text { yang diuji }\end{array}$} & \multicolumn{2}{|c|}{$\begin{array}{c}\text { Uji } \\
\text { Normalitas }\end{array}$} & \multicolumn{2}{|c|}{$\begin{array}{c}\text { Uji } \\
\text { Multikolinearitas }\end{array}$} & \multirow{2}{*}{$\begin{array}{c}\text { Uji } \\
\text { Heteroskedastisitas } \\
\text { Sig. }\end{array}$} & \multirow{2}{*}{$\begin{array}{c}\text { Uji } \\
\text { Autokorelasi } \\
\text { DW } \\
\end{array}$} \\
\hline & $\mathbf{Z}$ & $\mathbf{P}$ & Tolerance & VIF & & \\
\hline $\begin{array}{l}\text { Unstandarized } \\
\text { Residual }\end{array}$ & 0,081 & 0,200 & & & & \\
\hline FD & & & 0,816 & 1,225 & 0,991 & \\
\hline GCG & & & 0,816 & 1,225 & 0,110 & \\
\hline Durbin-Watson & & & & & & 1,700 \\
\hline
\end{tabular}

Sumber: Data diolah, 2017 
Tabel 5.

Hasil Uji Asumsi Klasik Persamaan Regresi 2

\begin{tabular}{|c|c|c|c|c|c|c|}
\hline \multirow{2}{*}{$\begin{array}{l}\text { Parameter } \\
\text { yang diuji }\end{array}$} & \multicolumn{2}{|c|}{$\begin{array}{c}\text { Uji } \\
\text { Normalitas } \\
\end{array}$} & \multicolumn{2}{|c|}{$\begin{array}{c}\text { Uji } \\
\text { Multikolinearitas }\end{array}$} & \multirow{2}{*}{$\begin{array}{c}\text { Uji } \\
\text { Heteroskedastisitas } \\
\text { Sig. } \\
\end{array}$} & \multirow{2}{*}{$\begin{array}{c}\text { Uji } \\
\text { Autokorelasi } \\
\text { DW } \\
\end{array}$} \\
\hline & $\mathbf{Z}$ & $\mathbf{P}$ & Tolerance & VIF & & \\
\hline $\begin{array}{l}\text { Unstandarized } \\
\text { Residual }\end{array}$ & 0,097 & 0,200 & & & & \\
\hline FD & & & 0,712 & 1,405 & 0,386 & \\
\hline GCG & & & 0,734 & 1,362 & 0,585 & \\
\hline ARL & & & 0,689 & 1,452 & 0.115 & \\
\hline Durbin-Watson & & & & & & 2,128 \\
\hline
\end{tabular}

Uji normalitas bertujuan untuk menguji apakah dalam sebuah model regresi variabel independen dan variabel dependen berdistribusi normal atau tidak. Berdasarkan Tabel 4 dan Tabel 5 di atas, nilai Kolmogorov-Smirnov menunjukan bahwa model persamaan regresi dalam penelitian ini berdistribusi normal karena nilai Asymp. Sig. (2-tailed) $>0,05$.

Uji multikolinieritas bertujuan untuk menguji apakah model regresi dalam penelitian ini ditemukan adanya hubungan antara variabel independen. Tabel 4 dan Tabel 5 di atas, menunjukan bahwa bahwa nilai tolerance untuk setiap variabel yang diujikan lebih besar dari 0,10 dan VIF lebih kecil dari 10. Hal ini menunjukkan bahwa variabel independen tidak saling berhubungan, sehingga dapat disimpulkan model regresi yang ada bebas multikolinearitas.

Uji heteroskedastisitas bertujuan untuk menguji apakah dalam model regresi dalam penelitian ini terjadi ketidaksamaan variance dari residual satu pengamatan ke pengamatan yang lain. Tabel 4 dan Tabel 5 di atas menunjukan bahwa tingkat signifikansi variabel FD, GCG, dan ARL berada di atas 0,05 sehingga dapat disimpulkan model regresi yang ada bebas heteroskedastisitas. 
Uji autokorelasi bertujuan untuk menguji apakah dalam model regresi linier ada korelasi antara kesalahan pengganggu pada periode t dengan kesalahan pengganggu pada periode t-1 (sebelumnya). Tabel 4 dan Tabel 5 di atas menunjukan pengujian Durbin Watson (DW) berada pada daerah tidak terdapat autokorelasi sehingga dapat disimpulkan bahwa kedua model regresi tidak terdapat gejala autokorelasi.

Pengujian data dalam penelitian ini menggunakan analisis jalur (path analysis) yang merupakan perluasan dari analisis regresi linier berganda yang digunakan untuk menguji hubungan sebab-akibat antara dua atau lebih variabel. Perhitungan koefisien jalur ditunjukkan pada tabel berikut.

Tabel 6.

Hasil Analisis Jalur Persamaan Regresi 1

\begin{tabular}{llrrrrr}
\hline & \multicolumn{7}{c}{$\begin{array}{c}\text { Unstandardized } \\
\text { Coefficients }\end{array}$} & $\begin{array}{c}\text { Standardized } \\
\text { Coefficients }\end{array}$ \\
\cline { 3 - 7 } \multicolumn{1}{c}{ Model } & & \multicolumn{1}{c}{ B } & \multicolumn{1}{c}{ Std. Error } & \multicolumn{1}{c}{ Beta } & \multicolumn{1}{c}{ t } & \multicolumn{1}{c}{ Sig. } \\
\hline 1 & (Constan) & 60,629 & 20,516 & & 2,955 & 0,005 \\
& FD & 9,110 & 3,665 & 0,352 & 2,486 & 0,017 \\
& GCG & $-12,216$ & 5,634 & $-0,307$ & $-2,168$ & 0,036 \\
\hline
\end{tabular}

Sumber: Data diolah, 2017

Persamaan struktural hasil analisis jalur substruktur 1 seperti yang disajikan pada tabel 6 adalah sebagai berikut.

$\mathrm{M}=\beta_{1} \mathrm{X}_{1}+\beta_{2} \mathrm{X}_{2}+\varepsilon_{1}$

$$
=0,352 X_{1}+(-0,307) X_{2}+\varepsilon_{1}
$$

Tabel 7.

Analisis Jalur Persamaan Regresi 2

\begin{tabular}{rlrrrrr}
\hline & \multicolumn{7}{c}{$\begin{array}{c}\text { Unstandardized } \\
\text { Coefficients }\end{array}$} & $\begin{array}{c}\text { Standardized } \\
\text { Coefficients }\end{array}$ \\
\cline { 3 - 8 } Model & & B & Std. Error & Beta & \multicolumn{1}{c}{ t } & \multicolumn{1}{c}{ Sig. } \\
\hline 1 & (Constan) & 24,920 & 26,765 & & 0,931 & 0,357 \\
& FD & 0,655 & 4,659 & 0,020 & 0,141 & 0,889 \\
& GCG & $-0,422$ & 7,052 & $-0,009$ & $-0,060$ & 0,953 \\
& ARL & 0,754 & 0,183 & 0,607 & 4,119 & 0,000 \\
\hline
\end{tabular}


Persamaan struktural hasil analisis jalur substruktur 2 seperti yang disajikan pada tabel 7 adalah sebagai berikut.

$$
\begin{aligned}
& \mathrm{Y}=\beta_{3} \mathrm{X}_{1}+\beta_{4} \mathrm{X}_{2}+\beta_{5} \mathrm{M}+\varepsilon_{2} \\
& =0,020 \mathrm{X}_{1}+(-0,009) \mathrm{X}_{2}+0,607 \mathrm{M}+\varepsilon_{2}
\end{aligned}
$$

Tabel 8.

Ringkasan Koefisien Jalur dan Signifikansi Hubungan Antarvariabel

\begin{tabular}{cccccl}
\hline \multicolumn{1}{c}{ Regresi } & $\begin{array}{c}\text { Koef. Reg. } \\
\text { Standar }\end{array}$ & $\begin{array}{c}\text { Standard } \\
\text { Error }\end{array}$ & t hitung & P. Value & \multicolumn{1}{c}{ Keterangan } \\
\hline $\mathrm{X}_{1} \rightarrow \mathrm{M}$ & 0,352 & 3,665 & 2,486 & 0,017 & Signifikan \\
$\mathrm{X}_{2} \rightarrow \mathrm{M}$ & $-0,307$ & 5,634 & $-2,168$ & 0,036 & Signifikan \\
$\mathrm{X}_{1} \rightarrow \mathrm{Y}$ & 0,020 & 4,659 & 0,141 & 0,889 & Non Signifikan \\
$\mathrm{X}_{2} \rightarrow \mathrm{Y}$ & $-0,009$ & 7,052 & $-0,060$ & 0,953 & Non Signifikan \\
$\mathrm{M} \rightarrow \mathrm{Y}$ & 0,607 & 0,183 & 4,119 & 0,000 & Signifikan \\
\hline
\end{tabular}

Berdasarkan tabel 8 dapat dijelaskan bahwa financial distress $\left(\mathrm{X}_{1}\right)$ dan GCG $\left(\mathrm{X}_{2}\right)$ berpengaruh signifikan terhadap audit report lag $(\mathrm{M})$, namun tidak signifikan terhadap ketepatan waktu publikasi laporan keuangan (Y). Sedangkan audit report lag $(\mathrm{M})$ berpengaruh signifikan terhadap ketepatan waktu publikasi laporan keuangan $(\mathrm{Y})$.

Sebelum menyusun model diagram jalur akhir, terlebih dahulu dihitung standar errornya sebagai berikut.

$\varepsilon=\sqrt{\left(1-r_{1}^{2}\right)}$

$\varepsilon_{1}=\sqrt{(1-0,311)}=0,830$

$\varepsilon_{2}=\sqrt{(1-0,386)}=0,783$

$\mathrm{Rm}^{2}=1-\left(0,830^{2} \times 0,783^{2}\right)$

$\mathrm{Rm}^{2}=1-0,422$

$\mathrm{Rm}^{2}=0,578$ 
Koefisien determinasi total sebesar 0,578 memiliki arti bahwa sebesar 57,8 persen informasi yang terkandung dalam penelitian ini dapat dijelaskan oleh model yang dibentuk, sedangkan sisanya yaitu 42,2 persen dijelaskan oleh variabel lain yang tidak dibahas dalam penelitian. Jika ditunjukan dalam bentuk model jalur, maka nilai koefisien jalur dan nilai standar errornya akan tampak pada Gambar 1 sebagai berikut.

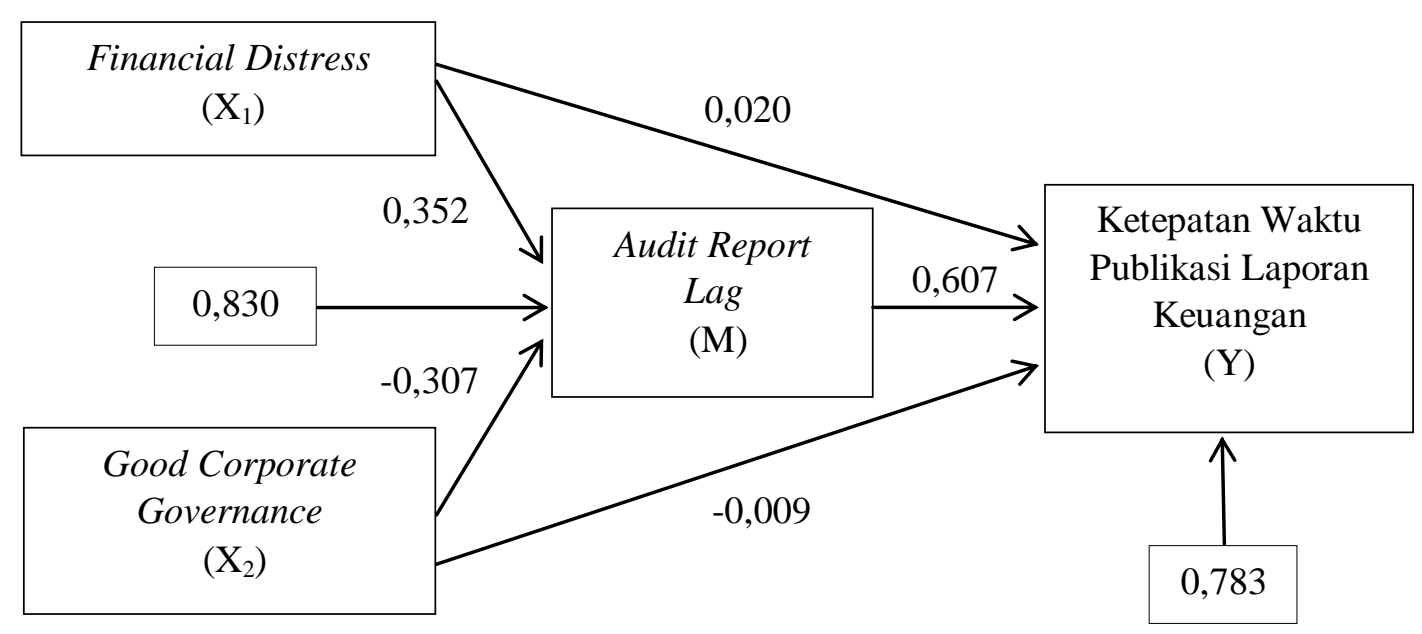

Sumber: Data diolah, 2017

\section{Gambar 1. Model Analisis Jalur}

Berdasarkan diagram jalur di atas, maka perhitungan pengaruh langsung, pengaruh tidak langsung, dan pengaruh total antar variabel dirangkum dalam Tabel 9 sebagai berikut.

Tabel 9.

Pengaruh Langsung, Pengaruh Tidak Langsung, dan Pengaruh Total

\begin{tabular}{cccc}
\hline $\begin{array}{c}\text { Pengaruh } \\
\text { Variabel }\end{array}$ & Pengaruh Langsung & $\begin{array}{c}\text { Pengaruh Tidak Langsung } \\
(\text { melalui ARL) }\end{array}$ & $\begin{array}{c}\text { Pengaruh Total } \\
(\text { PL + PTL) }\end{array}$ \\
\hline $\mathrm{X}_{1} \rightarrow \mathrm{M}$ & $\beta_{1}=0,352$ & & 0,352 \\
$\mathrm{X}_{2} \rightarrow \mathrm{M}$ & $\beta_{2}=-0,307$ & & $-0,307$ \\
$\mathrm{X}_{1} \rightarrow \mathrm{Y}$ & $\beta_{3}=0,020$ & $\beta_{1} \times \beta_{5}=0,213$ & 0,233 \\
$\mathrm{X}_{2} \rightarrow \mathrm{Y}$ & $\beta_{4}=-0,009$ & $\beta_{2} \times \beta_{5}=-0,186$ & $-0,195$ \\
$\mathrm{M} \rightarrow \mathrm{Y}$ & $\beta_{5}=0,607$ & & 0,607 \\
\hline \multicolumn{2}{l}{ Sumber: Data diolah, 2017}
\end{tabular}


Langkah terakhir dalam path analysis yaitu interpretasi hasil. Interpretasi hasil analisis jalur ini dimaksudkan untuk mengetahui peran variabel intervening (mediasi). Berdasarkan hasil analisis jalur di atas, dapat diketahui bahwa pengaruh financial distress $\left(\mathrm{X}_{1}\right)$ terhadap audit report lag $(\mathrm{M})$ memiliki nilai signifikansi atau sig t sebesar 0,017 . Nilai sig t $0,017<0,05$, maka terdapat pengaruh langsung antara variabel independen dengan variabel mediasi. Pengaruh GCG $\left(\mathrm{X}_{2}\right)$ terhadap audit report lag $(\mathrm{M})$ memiliki nilai signifikansi atau sig $\mathrm{t}$ sebesar 0,036 . Nilai sig $\mathrm{t}$ $0,036<0,05$, maka terdapat pengaruh langsung antara variabel independen dengan variabel mediasi.

Pengaruh audit report lag (M) terhadap ketepatan waktu publikasi laporan keuangan (Y) memiliki nilai signifikansi atau sig t sebesar 0,000. Nilai sig t 0,000 $<0,05$, maka terdapat pengaruh langsung antara variabel mediasi dengan variabel dependen. Pengaruh financial distress $\left(\mathrm{X}_{1}\right)$ terhadap ketepatan waktu publikasi laporan keuangan (Y) memiliki nilai signifikansi atau sig t sebesar 0,889. Nilai sig t $0,889>0,05$, maka tidak terdapat pengaruh langsung antara variabel independen dengan variabel dependen. Pengaruh GCG $\left(\mathrm{X}_{2}\right)$ terhadap ketepatan waktu publikasi laporan keuangan (Y) memiliki nilai signifikansi atau sig t sebesar 0,953. Nilai sig t $0,953>0,05$, maka tidak terdapat pengaruh langsung antara variabel mediasi dengan variabel dependen.

Pengujian hipotesis pengaruh tidak langsung mengacu pada penelitian yang dilakukan oleh Solimun dkk. (2017). Pemeriksaan atas adanya pengaruh mediasi menggunakan metode pemeriksaan koefisien jalur. Hasil perhitungan sebelumnya didapat nilai koefisien $\beta_{1}=0,352(\operatorname{sig} \mathrm{t}=0,017)$, nilai koefisien $\beta_{2}=$ - 
$0,307(\operatorname{sig} \mathrm{t}=0,036)$, nilai koefisien $\beta_{3}=0,020(\operatorname{sig} \mathrm{t}=0,889)$, nilai koefisien $\beta_{4}=$ $-0,009(\operatorname{sig} \mathrm{t}=0,953)$, nilai koefisien $\beta_{5}=0,607(\operatorname{sig} \mathrm{t}=0,000)$. Berdasarkan hasil tersebut, audit report lag dikatakan sebagai variabel mediasi lengkap atau sempurna (complete mediation), karena $\beta_{1}$ dan $\beta_{5}$ signifikan, tetapi $\beta_{3}$ tidak signifikan, serta $\beta_{2}$ dan $\beta_{5}$ signifikan, tetapi $\beta_{4}$ tidak signifikan. Ini berarti bahwa audit report lag mampu memediasi hubungan financial distress dan GCG pada ketepatan waktu publikasi laporan keuangan.

Hipotesis $\mathrm{H}_{1}$ dalam penelitian ini adalah financial distress berpengaruh positif pada audit report lag. Berdasarkan hasil path analysis menunjukkan bahwa $\mathrm{H}_{0}$ ditolak dan $\mathrm{H}_{1}$ diterima, yang berarti bahwa financial distress memiliki pengaruh positif pada audit report lag. Saat perusahaan sedang menghadapi kesulitan keuangan, yang menandakan perusahaan tersebut kemungkinan akan mengalami kebangkrutan, maka auditor membutuhkan waktu yang lebih banyak lagi untuk mengetahui apa yang sebenarnya terjadi dalam perusahaan tersebut. Sehingga dengan bertambahnya waktu yang dibutuhkan oleh auditor sebelum membuat keputusan, cenderung akan memperpanjang waktu penyelesaian auditnya. Hasil penelitian ini konsisten dengan penelitian yang dilakukan oleh Dwipayani, dkk (2016), Walker dan David (2008), Praptika dan Rasmini (2016), Setyahadi (2012), dan Santosa (2016).

Hipotesis $\mathrm{H}_{2}$ dalam penelitian ini adalah GCG berpengaruh negatif pada audit report lag. Berdasarkan hasil path analysis menunjukkan bahwa $\mathrm{H}_{0}$ ditolak dan $\mathrm{H}_{1}$ diterima, yang berarti bahwa GCG berpengaruh negatif pada audit report lag. Penerapan kelima asas GCG secara konsisten sangatlah penting, karena dapat 
meningkatkan kualitas laporan keuangan dan kriteria laporan keuangan yang baik sudah terpenuhi. Adanya praktik GCG tersebut diharapkan tidak terjadi kecurangan dalam penyusunan laporan keuangan oleh manajemen yang dapat menyebabkan lamanya rentang waktu penyelesaian audit dan perusahaan dapat melakukan pengawasan terhadap auditor sehingga dapat mengurangi waktu penyelesaian audit. Hasil penelitian ini sesuai dengan penelitian yang dilakukan oleh DS dan Nelyumna (2016), Faishal dan Hadiprajitno (2015), dan Bemby S, et al. (2013).

Hipotesis $\mathrm{H}_{3}$ dalam penelitian ini adalah financial distress berpengaruh positif pada ketepatan waktu publikasi laporan keuangan. Berdasarkan hasil path analysis menunjukkan bahwa $\mathrm{H}_{0}$ diterima dan $\mathrm{H}_{1}$ ditolak, sehingga dapat disimpulkan bahwa financial distress tidak berpengaruh pada ketepatan waktu publikasi laporan keuangan. Prastiwi dkk. (2014) mengemukakan bahwa tidak terdapat pengaruh dari dua rasio yang terdapat dalam pengukuran Altman Z-Score yaitu profitabilitas dan likuiditas. Saputra dan Ramantha (2017) menyatakan bahwa profitabilitas tidak berpengaruh terhadap ketepatan waktu pelaporan keuangan. Sedangkan Ferdina dan Wirama (2017) menyatakan bahwa likuiditas tidak berpengaruh pata ketepatwaktuan laporan keuangan. Profitabilitas tidak mempengaruhi ketepatan waktu publikasi laporan keuangan karena perusahaan yang memiliki tingkat profitabilitas yang tinggi maupun yang rendah sama-sama menginginkan laporan keuangannya disampaikan secara tepat waktu. Likuiditas suatu perusahaan juga tidak menjadi faktor yang mempengaruhi perusahaan dalam menerbitkan laporan keuangannya. Perusahaan dengan nilai likuiditas yang 
kecil juga menginginkan untuk menyampaikan laporan keuangan dengan tepat waktu agar kemampuan dan kinerja perusahaan dalam melunasi hutangnya dapat diketahui oleh pihak kreditor. Penundaan penerbitan laporan keuangan akan menurunkan tingkat kepercayaan kreditor dalam menilai kemampuan dan kinerja perusahaan dalam membayar hutang perusahaannya. Alasan financial distress tidak mampu mempengaruhi ketepatan waktu penyampaian laporan keuangan juga dapat dilihat pada nilai rata-rata financial distress sebesar 2,2667 yang memiliki arti bahwa sebagian besar perusahaan sampel berada dalam grey area (tidak dapat ditentukan apakah perusahaan sedang sehat atau mengalami kebangkrutan). Hasil penelitian ini sejalan dengan penelitian yang dilakukan oleh Kadir (2008), Krisnanda dan Ratnadi (2017), Budiasih dan Saputri (2014), dan Robert (2015).

Hipotesis $\mathrm{H}_{4}$ dalam penelitian ini adalah GCG berpengaruh negatif pada ketepatan waktu publikasi laporan keuangan. Berdasarkan hasil path analysis menunjukkan bahwa $\mathrm{H}_{0}$ diterima dan $\mathrm{H}_{1}$ ditolak, sehingga dapat disimpulkan bahwa GCG tidak mampu mempengaruhi ketepatan waktu publikasi laporan keuangan. GCG tidak mampu mempengaruhi ketepatan waktu publikasi laporan keuangan dapat disebabkan karena GCG yang diproksikan dengan CGPI kurang mampu mencerminkan tata kelola perusahaan yang sesungguhnya pada tahun terkait. Hal tersebut dapat terjadi karena IICG mengumumkan hasil pemeringkatan dan nilai CGPI tahun sebelumnya pada tahun berikutnya. Pengaruh yang tidak signifikan tersebut juga dapat dilihat pada hasil analisis statistik deskriptif. Hasil analisis menunjukan bahwa rata-rata nilai GCG adalah 
sebesar 2,7333 yang artinya bahwa rata-rata perusahaan sampel dalam penelitian ini sudah mendekati kategori sangat terpercaya dalam CGPI, namun masih saja ada perusahaan yang mempublikasikan laporan keuangannya dengan rentang waktu yang sangat panjang, yaitu 120 hari yang hampir mendekati batas waktu regulasian. Penelitian ini sejalan dengan Fitriani (2011), McGee dan Yuan (2008), Budiasih dan Saputri (2014), dan Harnida (2015).

Hipotesis $\mathrm{H}_{5}$ dalam penelitian ini adalah audit report lag berpengaruh positif pada ketepatan waktu publikasi laporan keuangan. Berdasarkan hasil path analysis menunjukkan bahwa $\mathrm{H}_{0}$ ditolak dan $\mathrm{H}_{1}$ diterima, sehingga dapat disimpulkan bahwa audit report lag berpengaruh positif pada ketepatan waktu publikasi laporan keuangan. Keterlambatan publikasi laporan keuangan dapat mengindikasikan adanya masalah dalam laporan keuangan perusahaan sehingga memerlukan waktu yang lebih lama dalam penyelesaian audit. Hasil penelitian ini sejalan dengan Ahmed dan Hossain (2010), Persephony (2013), Dinita (2011), dan Putri dkk. (2017).

Hipotesis $\mathrm{H}_{6}$ dalam penelitian ini adalah financial distress berpengaruh pada ketepatan waktu publikasi laporan keuangan melalui audit report lag. Pengujian hipotesis $\mathrm{H}_{6}$ menunjukkan bahwa $\mathrm{H}_{0}$ ditolak dan $\mathrm{H}_{1}$ diterima. Hasil tersebut membuktikan bahwa financial distress berpengaruh pada ketepatan waktu publikasi laporan keuangan melalui audit report lag. Perusahaan yang menghadapi kesulitan keuangan akan cenderung mengalami penyelesaian audit yang lebih panjang karena auditor membutuhkan waktu yang lebih banyak untuk mengetahui apa yang sebenarnya terjadi di dalam perusahaan tersebut. Lamanya 
rentang waktu penyelesaian audit tentu akan menyebabkan peningkatan waktu publikasi laporan keuangan yang artinya perusahaan akan semakin tidak tepat waktu dalam menyampaikan laporan keuanganya kepada publik. Hasil penelitian ini sejalan dengan Setyahadi (2012), Santosa (2016), Dinita (2011), dan Putri dkk. (2017). Namun, hasil penelitian ini bertentangan dengan penelitian Persephony (2013) yang menyatakan bahwa probabilitas kebangkrutan tidak mampu mempengaruhi waktu publikasi laporan keuangan melalui audit report lag.

Hipotesis $\mathrm{H}_{7}$ dalam penelitian ini adalah GCG berpengaruh pada ketepatan waktu publikasi laporan keuangan melalui audit report lag. Pengujian hipotesis $\mathrm{H}_{7}$ menunjukan bahwa $\mathrm{H}_{0}$ ditolak dan $\mathrm{H}_{1}$ diterima. Hasil tersebut membuktikan bahwa GCG berpengaruh pada ketepatan waktu publikasi laporan keuangan melalui audit report lag. Adanya praktik corporate governance diharapkan tidak terjadi kecurangan dalam penyusunan laporan keuangan oleh manajemen yang dapat menyebabkan lamanya waktu penyelesaian audit. Ketika pelaksanaan tata kelola perusahaan baik, maka perusahaan akan cenderung mempercepat publikasi laporan keuangannya karena terdapat pengendalian internal yang baik sebagai salah satu syarat pelaksanaaan GCG. Adanya penerapan GCG juga diharapkan perusahaan dapat melakukan pengawasan terhadap auditor sehingga dapat mengurangi lamanya waktu penyelesaian audit. Jadi, semakin baik tata kelola suatu perusahaan maka akan semakin pendek audit report lagnya sehingga publikasi laporan keuangan ke publik semakin tepat waktu. Penelitian ini sejalan dengan DS dan Nelyumna (2016), Faishal dan Hadiprajitno (2015), Dinita (2011), dan Putri dkk. (2017). 


\section{SIMPULAN}

Simpulan dalam penelitian ini yang didasarkan pada hasil analisis dan pembahasan yang telah dilakukan adalah financial distress berpengaruh positif pada audit report lag. GCG berpengaruh negatif pada audit report lag. Financial distress dan GCG tidak berpengaruh pada ketepatan waktu publikasi laporan keuangan. Audit report lag berpengaruh positif pada ketepatan waktu publikasi laporan keuangan. Financial distress dan GCG berpengaruh pada ketepatan waktu publikasi laporan keuangan melalui audit report lag.

Berdasarkan simpulan di atas, maka saran untuk penelitian selanjutnya dan pihak-pihak yang berkepentingan adalah bagi peneliti selanjutnya diharapkan agar menyesuaikan jumlah perusahaan yang digunakan dengan jumlah perusahaan pada CGPI tahun terbaru untuk menambah jumlah perusahaan yang akan digunakan, atau dapat menggunakan metode pengukuran GCG yang berbeda agar dapat memperoleh sampel yang lebih banyak. Bagi perusahaan diharapkan untuk ikut serta dalam penilaian GCG yang dilakukan oleh IICG agar memperoleh skor pemeringkatan CGPI. Hal tersebut penting karena bagi pihak eksternal perusahaan, dengan adanya pemeringkatan tersebut dapat memberikan gambaran mengenai penerapan GCG di dalam perusahaan dan hal tersebut dapat menjadi nilai tambah dimata investor.

\section{REFERENSI}

Ahmad, Raja Adzrin Raja, and Khairul Anuar Bin Kamarudin. 2003. Audit Delay and the Timeliness of Corporate Reporting: Malaysian Evidence, hal. 117.

Ahmed, A. A. A., and Md. Shakawat Hossain. 2010. Audit report lag: A study of the Bangladeshi listed companies. ASA University Review, 4(2), hal. 4956. 
Alkhatib, Khalid, and Qais Marji. 2012. Audit Reports Timeliness: Empirical Evidence from Jordan. Procedia - Social and Behavioral Sciences, 62, pp. 1342-1349.

Aziz, A. A., Fadlizawati I. dan Mohd F. A. 2014. Audit Reports Lags of Federal Statutory Bodies in Malaysia. International Conference on Economic, Management and Development.

Bemby S, B., Abukosim, Mukhtaruddin, dan Imam Mursidi. 2013. Good Corporate Governance (GCG) Mechanism and Audit Delay: An Empirical Study on Companies Listed on the Indonesia Stock Exchange (IDX) in the Period of 2009-2011. Journal of Modern Accounting and Auditing, 9(11), hal.1454-1468.

Budiasih, I. G. A. N., dan P Dwi A. S. 2014. Corporate Governance dan Financial Distress pada Kecepatan Publikasi Laporan Keuangan. KINERJA, 18(2), hal.157-167.

Clatworthy, M. A., 2010. Does Corporate Governance Influence the Timeliness of Financial Reporting? Evidence from UK Private Companies. Research Seminar Accounting and Management Control Department, hal. 19-20.

Dewi, Kadek Indah Kusuma dan Ni Made Dwi Ratnadi. 2016. Pengaruh Umur Perusahaan, Audit Tenure dan Good Corporate Governance pada Kecepatan Publikasi Laporan Keuangan. E-Jurnal Akuntansi Universitas Udayana, 15(1), hal. 463-494.

Dinita, Iffani. 2011. Pengaruh Opini Audit dan Audit Report Lag terhadap Ketepatan Waktu Penyampaian Laporan Keuangan dengan Reputasi KAP sebagai Variabel Moderating pada Perusahaan Manufaktur di Bursa Efek Indonesia (BEI). Skripsi Jurusan Akuntansi Fakultas Ekonomi Universitas Negeri Semarang, Semarang.

Ds, Amelia Oktrivina dan Nelyumna. 2016. Pengaruh Good Corporate Governance dan Auditor Eksternal Terhadap Audit Delay (Studi Empiris pada Perusahaan Industri Perbankan di Bursa Efek Indonesia 2011-2013).

Efobi, U., and P Okougbo. 2014. Timeliness of Financial Reporting in Nigeria. South African Journal of Accounting Research, 28(1), pp: 65-77.

F. Ben, D., Richard A. Bernardi, and Roger Williams. 2001. Improvement In Audit Report Lag And Reporting Timeliness: A Non-Event For Technology Advances. Journal of Business \& Economics Research, 1(2), hal. 1-12.

Faishal, M., dan Hadiprajitno, P. B. 2015. Pengaruh Mekanisme Good Corporate Governance Terhadap Audit Report Lag. Diponegoro Journal of Accounting, 4(4), hal. 1-11.

Ferdina, Ni Wayan Ajeng dan Dewa Gede Wirama. 2017. Pengaruh Profitabilitas, Leverage, Likuiditas dan Ukuran Perusahaan pada Ketepatwaktuan 
Laporan Keuangan. E-Jurnal Akuntansi Univeristas Udayana, 19(3), hal. 2293-2318.

Fitriani, Anisa. 2011. Pengaruh Kinerja Keuangan, Size, dan Good Corporate Governance Perusahaan Terhadap Timeliness. Skripsi Sarjana Jurusan Akuntansi Universitas Sebelas Maret, Surakarta.

Harnida, Muthia. 2015. Pengaruh Mekanisme Corporate Governance Terhadap Ketepatan Waktu Penyampaian Laporan Keuangan: Studi Empiris pada Perusahaan Publik yang Terdaftar di Bursa Efek Indonesia. JSAI, 2(1), hal. 25-36.

Hilmi, Utari dan Syaiful Ali, 2008. Analisis Faktor-Faktor yang Mempengaruhi Ketepatan Waktu Penyampaian Laporan Keuangan (Studi Empiris pada Perusahaan-Perusahaan yang Terdaftar Di BEJ Periode 2004-2006). Simposium Nasional Akuntansi XI Pontianak.

Jensen, M. and W. Meckling. 1976. Theory of the Firm: Managerial Behavior, Agency costs and Ownership structure. Journal of Financial Economic, 3 (4), hal. 305-360

Julien, Ricco Francois. 2013. Pengaruh Tingkat Profitabilitas, Financial Distress, dan Pelaporan Rugi Bersih Klien Terhadap Audit Report Lag Perusahaan Manufaktur yang Terdaftar di Bursa Efek Indonesia. Skripsi Program Studi Akuntansi Universitas Lampung, Bandar Lampung.

Kadir, A. 2008. Faktor-Faktor yang Berpengaruh Terhadap Ketepatwaktuan Pelaporan Keuangan. Tesis Program Pascasarjana Magister Sains Akuntansi Universitas Diponegoro.

Kartika, A. 2009. Faktor-Faktor yang Mempengaruhi Audit Delay di Indonesia (Studi Empiris pada Perusahaan-Perusahaan LQ 45 yang Terdaftar di Bursa Efek Jakarta). Jurnal Bisnis Dan Ekonomi, 16(1), hal. 1-17.

Krisnanda, I Gede Wahyu dan Ni Made Dwi Ratnadi. 2017. Pengaruh Financial Distress, Umur Perusahaan, Audit Tenure, Kompetensi Dewan Komisaris pada Kecepatan Publikasi Laporan Keuangan. E-Jurnal Akuntansi Universitas Udayana, 20 (3), hal. 1933-1960.

Mardyana, R. 2014. Effect of Good Corporate Governance, Financial Distress and Financial Performance on Timeliness of Financial Statements Reporting. Journal International Program in Accounting, Economics Business Faculty. 1 (3).

McGee, R.W. dan Yuan, X. 2008. Corporate Governance And The Timeliness Of Financial Reporting : A Empirical Study Of People Republic of China. International Journal of Business, Accounting and Finance, forthcoming.

Mohamad-Nor, M. N., Rohami, S., and Wan-Hussin, W. N. 2010. Corporate governance and audit report lag in Malaysia. Asian Academy of 
Management Journal of Accounting and Finance, 6(2), hal. 57-84.

Mumtaz, Ni'am Al. 2011. Pengaruh Kualitas Good Corporate Governance dan Karakteristik Perusahaan Terhadap Ketepatan Waktu Penyampaian Laporan Keuangan (Studi pada Perusahaan Publik Non-perbankan dan Jasa Keuangan Lainnya yang Terdaftar di BEI). Skripsi Sarjana Jurusan Akuntansi pada Fakultas Ekonomi Universitas Muhammadiyah, Surakarta.

Narayana, D. G. A. 2016. Pengaruh Struktur Kepemilikan, Financial Distress dan Audit Tenure pada Ketepatwaktuan Publikasi Laporan Keuangan. Skripsi Jurusan Akuntansi pada Fakultas Ekonomi dan Bisnis Universitas Udayana, Denpasar.

Owusu-Ansah, S., 2000. Timeliness of Corporate Reporting in Emerging Capital Markets: Empirical Evidence from Zimbabwe Stock Exchange. Accounting and Bussiness Rese- arch. Summer: hal. 243-254.

Owusu-Ansah, S., \& Yeoh, J. (2005). The effect of legislation on corporate disclosure practices. Abacus, 41(1), hal. 92-109.

Persephony, E. 2013. Pengaruh Ukuran Perusahaan, Reputasi Kantor Akuntan Publik dan Probabilitas Kebangkrutan terhadap Waktu Publikasi Laporan Keuangan dengan Audit Report Lag sebagai Variabel Intervening. Skripsi Jurusan Akuntansi Fakultas Ekonomi Universitas Negeri Semarang, Semarang.

Platt, H.D. dan Platt, M.B., 2002. Predicting Corporate Financial Distress: Reflections on Choice-based Samle Bias, Journal of Economics and Finance Illinois.

Praptika, P. Y. H., dan Rasmini, N. K. 2016. Pengaruh Audit Tenure, Pergantian Auditor, dan Financial Distress pada Audit Delay pada Perusahaan Consumer Goods. E-Jurnal Akuntansi Univeristas Udayana, 15(3), hal. 2052-2081.

Prastiwi, Evi Deliana, Gede Adi Yuniarta, dan Nyoman Ari Surya Darmawan. 2014. Pengaruh Profitabilitas dan Likuiditas Terhadap Ketepatan Waktu Pelaporan Keuangan. E-Journal S1 Ak Universitas Pendidikan Ganesha, 2(1).

Putri, Novianti., Pupung Purnamasari., dan Mey Maemunah. 2017. Pengaruh Opini Audit dan Audit Report Lag terhadap Ketepatan Waktu Penyampaian Laporan Keuangan dengan Tenure Audit Sebagai Variabel Moderasi (Studi pada Perusahaan Pertambangan yang Terdaftar di Bursa Efek Indonesia Periode Tahun 2013-2015). Prosiding Akuntansi, 3(2), hal. 312-318.

Robert, Kenny. 2015. Pengaruh Konvergensi IFRS, Probabilitas Kebangkrutan, dan Penerapan Good Corporate Governance Terhadap Ketepatwaktuan 
Penyampaian Laporan Keuangan (Studi pada Perusahaan Tambang di BEI Periode 2009-2013). Skripsi Sarjana Jurusan Pendidikan Akuntansi Universitas Negeri Yogyakarta, Yogyakarta.

Saputra, Komang Wahyu Surya dan I Wayan Ramantha. 2017. Pengaruh Profitabilitas dan Ukuran Perusahaan Terhadap Ketepatan Waktu Pelaporan Keuangan dengan Opini Audit sebagai Pemoderasi. E-Jurnal Akuntansi Univeristas Udayana, 20(2), hal. 1592-1620.

Setyahadi, R. R. 2012. Pengaruh Probabilitas Kebangkrutan pada Audit Delay. Tesis Program Pascasarjana Universitas Udayana, Denpasar.

Solimun, Adji Achmad Rinaldo Fernandes, dan Nurjannah. 2017. Metode Statistika Multivariat (Pemodelan Persamaan Struktural (SEM) Pendekatan WarpPLS). Malang: UB Press.

Sugita, K., dan Dwirandra, A. A. N. B. 2017. Ukuran KAP Memoderasi Pengaruh Financial Distress dan Ukuran Perusahaan Klien pada Audit Report Lag. E-Jurnal Akuntansi Univeristas Udayana, 21(1), hal. 477-504.

Utami, W. 2006. Analisis Determinan Audit Delay Kajian Empiris di Bursa Efek Jakarta. Bulletin Penelitian, 09, hal. 19-31.

Widyastuti, E. 2010. Pengaruh Karakteristik Perusahaan dan Kualitas Good Corporate Governance Terhadap Ketepatan Waktu Penyampaian Laporan Keuangan Perusahaan (Studi Kasus pada Perusahaan Publik Nonperbankan dan Jasa Keuangan Lainnya yang Terdaftar di BEI). Skripsi. Sarjana Jurusan Akuntansi pada Fakultas Ekonomi Universitas Muhammadiyah, Surakarta. 